Volume 65

Issue 2 Winter 2016 Twenty-First Annual

Clifford Symposium on Tort Law and Social

Article 7 Policy

\title{
The Supreme Court's Stealth Return to the Common Law of Torts
}

John C.P. Goldberg

Benjamin C. Zipursky

Follow this and additional works at: https://via.library.depaul.edu/law-review

Part of the Law Commons

\section{Recommended Citation}

John C. Goldberg \& Benjamin C. Zipursky, The Supreme Court's Stealth Return to the Common Law of Torts, 65 DePaul L. Rev. (2016)

Available at: https://via.library.depaul.edu/law-review/vol65/iss2/7

This Article is brought to you for free and open access by the College of Law at Digital Commons@DePaul. It has been accepted for inclusion in DePaul Law Review by an authorized editor of Digital Commons@DePaul. For more information, please contact digitalservices@depaul.edu. 


\title{
THE SUPREME COURT'S STEALTH RETURN TO THE COMMON LAW OF TORTS
}

\author{
John C.P. Goldberg* \& Benjamin C. Zipursky**
}

\section{INTRODUCTION}

Although it now enjoys a hallowed place in our legal history, Erie Railroad Co. v. Tompkins ${ }^{1}$ began as a plain-vanilla negligence case. Tompkins was struck by Erie's train while he was walking on a worn path alongside tracks near his Pennsylvania home. Because the path was on Erie's right of way, Tompkins' lawyers feared that Pennsylvania state and federal courts would follow Pennsylvania precedents and rule that Tompkins was a trespasser to whom Erie owed no duty of care. Hoping to take advantage of Swift v. Tyson's directive that federal courts should interpret "general law" according to "general reasoning and legal analogies," even if that meant departing from state court precedents, ${ }^{2}$ Tompkins filed suit in federal district court in New York. ${ }^{3}$

Tompkins' gambit initially worked. The district court declined to dismiss his suit, and a jury found in his favor. ${ }^{4}$ The U.S. Court of Appeals for the Second Circuit affirmed, taking the occasion to formulate a more plaintiff-friendly rule of general tort law than its counterpart in Pennsylvania law: "Where the public has made open and notorious use of a railroad right of way for a long period of time and without objection, the company owes to persons on such permissive pathway a duty of care in the operation of its trains." 5

Unfortunately and ironically for Tompkins-ironically because Swift had been mostly criticized for allowing corporate defendants to

* Eli Goldston Professor of Law, Harvard Law School.

** James H. Quinn '49 Professor of Legal Ethics, Fordham University School of Law. Thanks to John Manning and Mark Tushnet for very helpful comments. Thanks also to Harvard Law School and Fordham University School of Law for generously supporting our research.

1. 304 U.S. 64 (1938). Our description of the Erie litigation relies on Edward Purcell's excellent account. Edward A. Purcell, Jr., The Story of Erie: How Litigants, Lawyers, Judges, Politics, and Social Change Reshape the Law, in Civil Procedure Stories 21, 36-49 (Kevin M. Clermont ed., 2d ed. 2008).

2. 41 U.S. 1 (1842), overruled by Erie, 304 U.S. 64.

3. Erie, 304 U.S. at 67 . New York was Erie's state of incorporation.

4. Id. at 70 .

5. Tompkins v. Erie R.R. Co., 90 F.2d 603, 604 (2d Cir. 1937), rev'd, 304 U.S. 64 (1938). 
remove diversity cases to take advantage of defendant-friendly rules of general law6 - the Supreme Court reversed. Writing for a majority, Justice Brandeis declared unsound Swift's assertion that federal courts enjoy a power to fashion general law. Going forward, suits such as Tompkins' would be governed by substantive state law. Predictably, after it was remanded for adjudication under Pennsylvania tort law, Tompkins' suit was dismissed.

For those inclined to view the Court as primarily a political actor, Erie might seem puzzling. After all, its rejection of Swift was an act of self-disempowerment. The Court had conferred on itself a privileged position to shape contract, property, and tort law. Erie abandoned that position. Moreover, it did so at a moment of increasing economic nationalization in which there was a growing demand for uniform national laws. It is possible that the Court's renunciation was a shrewd bit of institutional self-preservation-one move in the strategic retreat famously dubbed the "switch in time." 7 More likely, the Erie majority believed it was doing the right thing-that the balance of constitutional, jurisprudential, and political reasons favored the federal courts getting out of the business of making general common law. Perhaps the Justices also believed that they were ceding a power that was relatively circumscribed (after all, under Swift, the Court could not force state courts to follow its interpretations of the general law) and that was destined to become more circumscribed in a world that would be increasingly governed by legislation and regulation.

Erie's holding has since been refined in many ways, generating lively debates over its proper interpretation. ${ }^{8}$ These debates aside, the decision clearly matters at a practical level. Manufacturers, for example, have since needed to comply with the negligence, warranty, and products liability laws of all U.S. jurisdictions. Variations among the states' tort doctrines are felt even by actors whose conduct is typically governed by the laws of only one jurisdiction, such as physicians facing malpractice liability. This is why lobbyists for defendants and insurers have regularly sought tort reform at the congressional level, although so far without much success.

At the same time, it would be an enormous mistake to equate Erie's disavowal of general law with a withdrawal by the Supreme Court

6. See Purcell, supra note 1, at 27, 48.

7. Burt Solomon, FDR v. The Constitution: The Court-Packing Fight and the TriUMPH OF DEMOCRACY 162 (2009) (noting uncertainty as to who first coined the "switch in time" phrase).

8. Edward A. Purcell, Jr., Brandeis and the Progressive Constitution: Erie, the Judicial Power, and the Politics of the Federal Courts in Twentieth-Century AMERICA 285-308 (2000) (discussing late twentieth-century debates over Erie). 
from tort law. After Erie, one does not find in the U.S. Reports precise counterparts to the Holmes-Cardozo, Goodman-Pokora interchange over the proper approach to contributory negligence in railroad grade-crossing accidents. ${ }^{9}$ Nonetheless, by the mid-1960s, the Court was actively making tort law, both directly and indirectly. In American tort law today, the Supreme Court is a major player.

To the extent commentators have underappreciated this development, it is in part because the Court's interventions have occurred on various fronts and taken various forms. Through interpretations of the federal Constitution and federal statutes, the Court has recognized (but also limited the scope of) new torts. These include Bivens actions, ${ }^{10}$ Title VII claims for hostile work environment discrimination, ${ }^{11}$ and securities fraud claims. ${ }^{12}$ Through its interpretation of other statutes, such as the Federal Employers' Liability Act (FELA) ${ }^{13}$ and the Federal Tort Claims Act (FTCA),${ }^{14}$ the Court has influenced state law on issues such as liability for medical monitoring, ${ }^{15}$ and it has preserved and arguably expanded sovereign immunity. ${ }^{16}$ In applying and interpreting procedural and evidentiary rules, the Justices have dramatically curtailed the use of class actions to resolve mass torts ${ }^{17}$ and have required plaintiffs to meet relatively demanding evidentiary requirements on issues such as design defect in products liability cases

9. Baltimore \& O.R. Co. v. Goodman, 275 U.S. 66 (1927) (Holmes, J.) (suggesting a rule under which drivers at certain grade crossings who fail to stop, look, and reconnoiter would be deemed contributorily negligent for ensuing collisions); Pokora v. Wabash Ry. Co., 292 U.S. 98 (1934) (Cardozo, J.) (rejecting Goodman's suggested rule as artificial and insufficiently responsive to the facts of individual cases).

10. See, e.g., Bivens v. Six Unknown Named Agents of Fed. Bureau of Narcotics, 403 U.S. 388 (1971) (recognizing an implied right of action for violations of Fourth Amendment rights).

11. See, e.g., Harris v. Forklift Sys., Inc., 510 U.S. 17 (1993) (holding that severe emotional distress is not an element of a hostile work environment claim); Meritor Sav. Bank, FSB v. Vinson, 477 U.S. 57 (1986) (defining the elements of a hostile work environment claim).

12. See, e.g., Basic Inc. v. Levinson, 485 U.S. 224 (1988) (recognizing fraud on the market as a viable theory of securities fraud); Ernst \& Ernst v. Hochfelder, 425 U.S. 185 (1976) (defining the elements of securities fraud claims brought under federal statutes and regulations).

13. Act of Apr. 22, 1908, ch. 149, as amended by Act of Apr. 5, 1910, ch. 145, 35 Stat. 65 (codified as amended at 45 U.S.C. $\$ \S 51-60$ (2012)).

14. Ch. 753 , $\S \S 401-24,60$ Stat. 842 (1946) (codified as amended in scattered sections of 28 U.S.C.).

15. See, e.g., Metro-North Commuter R.R. Co. v. Buckley, 521 U.S 424 (1997) (permitting claims for medical monitoring under FELA).

16. See, e.g., United States v. Gaubert, 499 U.S. 315 (1991) (interpreting the FTCA's discretionary function exception); Berkovitz v. United States, 486 U.S. 531 (1988).

17. See, e.g., Ortiz v. Fibreboard Corp., 527 U.S. 815 (1999) (denying certification of a settlement class based on a "limited fund" theory); Amchem Prods., Inc. v. Windsor, 521 U.S. 591 (1997) (affirming denial of class certification for failure to meet the criteria of Federal Rule of Civil Procedure 23). 
and causation in toxic tort cases. ${ }^{18}$ Finally, and most dramatically, through its interpretations of the First Amendment, the Fourteenth Amendment, and the Supremacy Clause, respectively, the Court has transformed defamation law, ${ }^{19}$ has set significant limits on punitive damages, ${ }^{20}$ and has deemed entire domains of products liability law preempted. ${ }^{21}$

We do not mean to suggest that, merely by getting involved in the matters just described, the Court has flouted Erie or otherwise acted inappropriately. Certainly none of these interventions rest on an explicit claim by the Court to enjoy a Swift-like power to fashion general law. Rather, each has been rooted in an interpretation and application of a federal statute or the federal Constitution. Yet, while the Court has hewed to the letter of Erie, it has increasingly lost touch with the notions of common law and federalism that seemed to animate that decision.

Erie was fueled by the idea that Swift had given the federal courts an inappropriate role within our federal system by providing a forum through which repeat-player tort defendants could seek, and often find, more favorable treatment than they tended to receive under state law. The federal courts were available to play this role partly because the political and legal leanings of the federal judiciary tended to diverge from those of state court judges and juries, and also because they gave sophisticated defense lawyers a chance to make arguments that tended to fare worse in state court. Erie called on the federal courts to respect the state courts as the authentic font of common law doctrine. Yet, the modern Court has increasingly allowed itself (and lower federal courts) to become a shadow lawmaker that provides relief to tort defendants dissatisfied with outcomes in state courts. Worse, it has done so not merely by giving relief to defendants who can find their way to federal court through removal but, instead, by fashioning law that is binding in courts throughout the United States.

18. See, e.g., Kumho Tire Co. v. Carmichael, 526 U.S. 137 (1999) (holding that the Daubert standard applies to all forms of expert testimony); Daubert v. Merrell Dow Pharm., Inc., 509 U.S. 579 (1993) (interpreting the Federal Rules of Evidence as requiring district courts to assess the validity of methods deployed by expert witnesses).

19. See infra notes 24-49 and accompanying text (discussing defamation decisions).

20. See, e.g., Philip Morris USA v. Williams, 549 U.S. 346 (2007) (identifying due process limits on the considerations jurors may take into account when awarding punitive damages); BMW of N. Am., Inc. v. Gore, 517 U.S. 559 (1996) (establishing due process guidelines for the size of punitive damage awards); Pac. Mut. Life Ins. Co. v. Haslip, 499 U.S. 1 (1991) (defining due process requirements for judicial review of punitive damage awards).

21. See infra notes 52, 108 and accompanying text (discussing preemption decisions). 
Although we believe that there are many examples of this phenomenon, this Article focuses on two. Part II examines New York Times Co. v. Sullivan, ${ }^{22}$ the Court's first great post-Erie foray into tort law. Sullivan is, of course, the starting point, but we follow the Court's efforts all the way to its recent decision in Snyder v. Phelps. ${ }^{23}$ In Part III, we consider the Court's burgeoning preemption decisions, which, given their massive curtailment of liability for product-related injuries, raise particularly urgent issues of legitimacy.

It is not surprising that the Supreme Court has found its way back into tort law. Tort law is not simply a local, small-stakes dispute resolution system for injured plaintiffs. Like criminal law and constitutional law, tort law is central in the operation of our legal system. Thus, on one level, it is entirely plausible that our top court should have something to say about it. Still, the Court's participation must be carefully examined to ensure that it is operating within the letter and the spirit of Erie's self-imposed restraints.

\section{Defamation, Privacy, and Infliction of Emotional Distress: From Sullivan to Gertz AND Beyond}

The modern Supreme Court's deepest and most widely accepted foray into tort law began in 1964 with Sullivan. For many reasons, Sullivan is not often associated with tort reform. Issued more than a decade before the initial wave of liability insurance 'crises' that gave rise to the modern tort reform movement, it was and is emblematic of the Warren Court's political progressivism. Moreover, the decision so plainly addresses a question of free speech that its constitutional component understandably obscures its tort component. Also, tort law tends these days to be (wrongly) thought of as accident law, and Sullivan has nothing to do with accidents. Beyond all these there is a more basic reason that the decision is not associated with tort law. However, we must delve further into the decision to appreciate this reason.

It is difficult to think of a more compelling case than Sullivan for Supreme Court intervention on behalf of a tort defendant. In the mid-1960s, the Court was a leader in the movement to end de jure segregation. The national media, based in New York and Washington, D.C., was a powerful ally in that movement, and Martin Luther King, Jr. was its most prophetic figure. City Commissioner L.B. Sullivan's libel suit was a direct attack on the national media and an indirect 
attack on King. ${ }^{24}$ The Alabama Supreme Court effectively endorsed that attack by: (1) stretching state tort law to hold the New York Times liable for publishing an advertisement that nowhere mentioned Sullivan or his office; (2) permitting compensatory damages with no evidence of actual harm; and (3) allowing punitive damages with little or no evidence of common law malice. It was thus hardly surprising that the Justices granted the newspaper's petition, ordered the dismissal of the lawsuit, and abandoned prior dictum asserting that defamatory speech is categorically unprotected. ${ }^{25}$

Sullivan presented such a strong case for recognition of First Amendment limits on 'tort' liability because it was a criminal prosecution dressed up as a civil defamation action. While putatively suing in his individual capacity, the plaintiff was a Montgomery city official. The supposedly libelous statements involved criticisms of abusive actions purportedly taken by city police against civil rights activists. ${ }^{26}$ Sullivan's claim of redress for reputational harm was not colorablethe obvious point of the suit was to obtain a punitive damages award that would cause the national media to shrink from covering segregation. In sum, this was a transparent effort by a government official, aided by sympathetic state judges, to use civil litigation to punish a newspaper for publishing criticisms of official actions and policies. The Alabama Supreme Court's affirmance of the plaintiff's verdict was a declaration that, when it came to critics of Jim Crow, the notorious common law crime of seditious libel was alive and well. ${ }^{27}$

Once the underlying suit in Sullivan is seen for what it really was, much about the Supreme Court's decision comes more sharply into focus. First, one can appreciate why Herbert Wechsler's famous brief to the Court regarding the Alien and Sedition Acts resonated so powerfully. ${ }^{28}$ Second, one can see why the Court was comfortable dealing with a potentially knotty state-action issue by means of a conclusory footnote: this nominally private lawsuit really was state action. Third, one readily appreciates the need for, and propriety of, the Court's intervention. If anything raises First Amendment flags, it is the criminalization of political speech.

\footnotetext{
24. See Gene Roberts \& Hank Klibanoff, The Race Beat: The Press, The Civil Rights Struggle, and the Awakening of a Nation 126-42 (2006) (providing an account of Alabama's efforts to stifle media coverage of civil rights issues).

25. See Sullivan, 376 U.S. at 292.

26. Id. at 256-59. According to the suit, because Sullivan's official responsibilities included nominal oversight of the police department, readers of the offending advertisement might have inferred that he had authorized or ratified the actions taken by police. Id.

27. See id. at 261-65.

28. Brief for the Petitioner at 40-49, Sullivan, 376 U.S. 254 (No. 39), 1963 WL 66441.
} 
These same features explain why Sullivan does not present itself as a straightforward instance of tort reform. Even though the decision revised tort doctrine by imposing the actual malice requirement and by narrowing the "of and concerning" element of the defamation torts as applied to statements about official action, it did so as part of an effort to set a boundary between tort and crime. Sullivan aimed to ensure that civil defamation actions did not operate as criminal or quasi-criminal proceedings, at least not without protections for defendants that included a robust mens rea standard and an absolute bar to punishment for speech about governmental actions in general, as opposed to speech about misdeeds of particular named officials.

Of course, soon after Sullivan, the Court dove deeper into civil defamation law. Some decisions expanded on Sullivan by making clear that a finding of actual malice requires proof by clear and convincing evidence of the defendant's subjective awareness of falsity or recklessness as to falsity. The Court further held that this issue was a matter of "constitutional fact," which was subject to hard-look appellate review. In Curtis Publishing Co. v. Butts, ${ }^{29}$ the Court extended the actual malice requirement to suits brought by public figures. ${ }^{30}$ More dramatically, in Gertz v. Robert Welch, Inc., ${ }^{31}$ which was issued ten years after Sullivan, the Court announced constitutional restrictions applicable to defamation suits brought by private figures based on speech addressing a matter of public concern. ${ }^{32}$ The Gertz majority held that, without proof of carelessness as to the truth of the defamatory statement, there can be no liability for this type of speech and, without proof of actual malice, there can be no presumed or punitive damages. ${ }^{33}$ In Philadelphia Newspapers, Inc. v. Hepps, ${ }^{34}$ the Court picked up on Gertz's offhand suggestion that "opinion" is constitutionally protected, ${ }^{35}$ and ruled that a plaintiff must prove the falsity of the defendant's defamatory speech. ${ }^{36}$ Finally, although Milkovich $v$. Lorain Journal Co. ${ }^{37}$ formally disavowed Gertz's suggestion that expressions of opinion enjoy a separate constitutional immunity from

29. 388 U.S. 130 (1967).

30. Id. at 160 . No doubt it helped that Curtis and its companion case involved suits by a former government employee (a retired military officer) and a quasi-employee of a public university (a football coach employed by an entity nominally separate from the university). Unlike, say, a film star, both of these public figures could be considered public officials.

31. 418 U.S. 323 (1974).

32. $I d$. at $347-49$.

33. Id.

34. 475 U.S. 767 (1986).

35. Gertz, 418 U.S. at 339-40.

36. Hepps, 475 U.S. at 775.

37. 497 U.S. 1 (1990). 
liability, it nonetheless reemphasized the importance of proving falsity. ${ }^{38}$ In doing so, it has encouraged lower courts to expand the domain of defamation claims that are dismissed on the ground that the defendant's statement amounts to a mere opinion containing no "falsifiable" claim about the plaintiff. ${ }^{39}$

Prior to Sullivan, a plaintiff could win a libel suit by proving by a preponderance of the evidence that the defendant published by writing or broadcast a defamatory statement about her to a third party. Generally, there was no need for the plaintiff to prove that: (1) the defendant was careless in making the statement (much less that she was reckless); (2) the statement caused the plaintiff actual injury; and (3) the statement was false. Punitive damages were difficult to obtain because the common law required willful or wanton misconduct, but a plaintiff's right to recover compensation for a damaged reputation was ample. There was no difference in the standards between cases involving public figures and those involving private figures; the phrase "public figure" was not part of the law of libel.

All of these features of the law of libel have changed dramatically since Sullivan. The requirement of proof of actual malice by clear and convincing evidence has dramatically curtailed defamation suits by officials and public figures; private figures are rarely able to take advantage of the common law doctrine of presumed damages and must now prove at least negligence to have a chance of recovering compensatory damages, assuming they can offer evidence of actual harm; and, a wide range of statements are deemed nondefamatory on the ground that they do not contain falsifiable or provably false statements. ${ }^{40}$ The Court, of course, has asserted that its authority to make these changes resides in the Free Speech Clause of the First Amendment. ${ }^{41}$ Still, given the level of doctrinal detail at which the Court has operated, it is hardly an exaggeration to assert that Sullivan and its progeny has produced a general law of libel.

Even this description understates Sullivan's significance. According to Westlaw, in the decades since it was decided, courts have cited Sullivan 6,439 times. ${ }^{42}$ By comparison, they have cited Brown v. Board

\footnotetext{
38. Id. at $17-21$.

39. See id.

40. See Milkovich v. Lorain Journal Co., 497 U.S. 1 (1990).

41. U.S. Const. amend. I, cl. 3.

42. New York Times Co. v. Sullivan Citing Decisions, Thompson Reuters: WestlawNext, http://next.westlaw.com (search "376 U.S. 254"; then follow "Citing References" hyperlink; then follow "Cases" hyperlink) (last visited Dec. 29, 2015).
} 
of Education 2,480 times. ${ }^{43}$ As we have noted, First Amendmentbased rulings by the Court that sprang from Sullivan have affected cases that fall entirely outside the law of defamation. Most notably, the Court has invoked the First Amendment to drastically curtail the tort of public disclosure of private facts. ${ }^{44}$ And, twice, in Hustler Magazine, Inc. v. Falwell ${ }^{45}$ and then recently in Snyder, the Court has held that the First Amendment limits liability for the intentional infliction of emotional distress (IIED) claims through outrageous conduct. ${ }^{46}$

Given the magnitude of the changes wrought by the Court's decisions, it might seem surprising that there is not a more developed literature critical of its transformation of defamation, privacy, and IIED law. There are, however, structural reasons for this relative silence. The law of defamation strikes many as resting on old-fashioned notions of honor and was, in any event, in need of updating when the Court decided to tackle it. Moreover, it is no secret that Justices on the left and right have each found much to like in expansive readings of the First Amendment. And, the media, which might otherwise place some aspects of the Court's jurisprudence under scrutiny, is among the principal beneficiaries of this one-sidedness.

Nonetheless, during an era in which arguments grounded in federalism are supposedly taken seriously, the virtual absence of any serious criticism of the Court's First Amendment torts decisions is startling. If ever there was a body of law that historically was the province of the states and that gave a central role to local community values, it was the law of defamation. At moments-as in Sullivan-defamation litigation has raised issues that must be resolved at a national level. Perhaps in the modern world of global media and costly litigation, any plausible understanding of free speech would have significant implications for how defamation law is fashioned. Nonetheless, it remains remarkable that an entire area of the common law of torts has been remade by the Supreme Court, acting in the manner of a Court still in the grips of Swift.

How did this transformation occur? A glib answer is "Gertz." There, a majority of the Court, based on reasoning very much akin to Swift's appeal to "general reasoning and legal analogies," decided that, in the modern world, all torts, including the defamation torts,

43. Brown v. Board of Education Citing Decisions, Thompson Reuters: WestLawNext, http://next.westlaw.com (search "347 U.S. 483"; then follow "Citing References" hyperlink; then follow "Cases" hyperlink) (last visited Dec. 17, 2015).

44. Florida Star v. B.J.F., 491 U.S. 524 (1989).

45. 485 U.S. 46 (1988).

46. See Snyder v. Phelps 562 U.S. 443, 459 (2011); Hustler, 485 U.S. at 50. 
ought to track the contours of the tort of negligence. ${ }^{47}$ Thus, it was essential to all (or almost all) libel and slander claims that the plaintiff prove the defendant's fault and the tangible harm suffered. Had the Court limited its interventions to defamation suits involving public officials and public figures, Sullivan's legacy would still be hugely important, but it would not have amounted to a general law of defamation.

A longer answer is that Sullivan was written on terms that invited this subsequent extension of constitutional doctrine. For while the case itself involved an effort to punish speech critical of government, the Court's key policy rationale-namely, the need to protect against the chilling effect of tort liability on speech-has an unbounded quality to it, one that renders much of the law of defamation (and privacy and IIED) incompatible with the First Amendment.

For this reason, Sullivan could not help but attract repeat-player defendants and their well-trained, well-paid attorneys to push for more protection against liability. No countervailing concentrated interests or professional expertise stood against them-defamation plaintiffs were typically represented by personal injury lawyers with no special expertise in that somewhat arcane body of law. Combining a tort-theoretic picture that equates tort law with negligence law and a sophisticate's skepticism about the small-minded moralism of common law libel, defense lawyers urged the Justices to see First Amendment arguments all the way through to their (supposedly) policydriven conclusions. This helps explain why, in Gertz, the Court decided that an assumption of risk defense (which never featured in the common law of defamation) defeats most claims by public figures ${ }^{48}$ while also deciding that, because all speech is valuable, strict liability could not apply to any defamation claim, liability without proof of actual injury is incoherent, and anything regarded as a statement of opinion could not be deemed tortious. ${ }^{49}$

Regardless of whether the Supreme Court was correct to extend Sullivan as far as it did, the ten-year arc from Sullivan to Gertz merits scholarly focus. It stands as an extraordinary example of how, notwithstanding Erie, the Court can become so deeply involved in tort cases that constitutional law displaces tort law. The Court was first lured into the area by a deeply troubling case that was entirely worthy of its attention. Because defendants qua petitioners had framed the case to invite Court action, it identified a federal law problem at the heart of an entire branch of tort law. The Court provided the peti-

47. Gertz v. Robert Welch, Inc., 418 U.S. 323, 349 (1974).

48. $I d$. at 345 .

49. Id. at $346-48$. 
tioner with relief on terms that generated a federal law hook for future defendants who quickly saw the potential for achieving favorable fifty-state tort reform through the invocation of the cherished constitutional value of free speech. Any remnant of Erie's concern regarding the proper place for the federal courts was lost in the ensuing revolution. Although it is by no means inconsistent with the spirit of Erie for the Court to reverse outlier decisions that raise serious constitutional concerns, it is quite another thing for the Court to treat the Constitution as empowering it to rework entirely a body of tort doctrine so that it better accords with the Justices' sensibilities about what a modern body of defamation law ought to look like.

\section{Preemption: From Cipollone to Geier and Beyond}

Our expressions of concern regarding the degree to which the Court has meddled with defamation law might seem overblown. Many would suppose that libel and slander lie at the periphery of modern tort law. Even if the Court has overreached in this area, they might say, this is hardly something to get up in arms about.

Complacency of this sort is unwarranted for several reasons. First, it is symptomatic of the very transformation wrought by the Court that we have identified as problematic. Second, one would have to know more about how the Court's massive reworking of defamation and privacy law has affected public and private life before concluding that the Court's work in those areas was harmless. Third, and most importantly, Sullivan set a pattern of court intervention that has since repeated itself. The Court's tussle with the Alabama Supreme Court in Sullivan, of course, largely replicated itself in BMW of North America, Inc. v. Gore, ${ }^{50}$ and, from there, a national law of punitive damages has emerged. Likewise, in Daubert v. Merrell Dow Pharmaceuticals, Inc. ${ }^{51}$ the Court's worry over proof of causation in toxic tort cases quickly extended to a general insistence that expert testimony-even on relatively prosaic matters in tort litigation-meet heightened standards of reliability. ${ }^{52}$ In each instance, federal law provided a hook: the First Amendment in Sullivan, the Fourteenth Amendment's Due Process Clause in $B M W$, and the Federal Rules of Evidence in Daubert. In each case, defendants thoughtfully packaged a federal issue that was intermingled with a state-law tort claim and persuaded the Court that something had gone very seriously wrong in

50. 517 U.S. 559 (1996)

51. 509 U.S. 579 (1993).

52. Kumho Tire Co. v. Carmichael, 526 U.S. 137 (1999) (holding that the Daubert standard applies to all forms of expert testimony). 
the courts below, such that the Court's attention was warranted. And, as to each, defense lawyers followed their victory in an initial landmark case with years of advocacy that resulted in revisions of tort law far beyond those achieved in the initial decision.

Perhaps the most timely and important example of this phenomenon involves the evolution of federal preemption doctrine. In this domain, Cipollone v. Liggett Group, Inc. ${ }^{53}$ is the Court's key decision. Although hardly on par with Sullivan as a landmark of modern law, Cipollone turns out to bear important similarities to that decision.

Like Sullivan, Cipollone involved a tort suit with significant political implications. Because of the substantial political and economic clout of tobacco companies, especially in certain regions, Congress faced a daunting task in regulating tobacco products. Thus, it was not until decades after the dangers of smoking were first documented that-in the face of the famous Surgeon General's report and the efforts of nontobacco states and the Federal Trade Commission to regulate cigarettes-Congress required manufacturers to put warning labels on cigarette packages. The Federal Cigarette Labeling and Advertising Act of 1965 (1965 Act) was a compromise of sorts. ${ }^{54}$ Cigarette packages were required to display a particular warning: "CAUTION: CIGARETTE SMOKING MAY BE HAZARDOUS TO YOUR HEALTH." 55 In return, however, the 1965 Act included an express preemption clause providing that no other "statement" relating to smoking and health could be "required" of cigarette manufacturers. ${ }^{56}$

The 1965 Act included a sunset clause, so Congress returned to tobacco safety in 1969. The Public Health Cigarette Smoking Act of 1969 (1969 Act $)^{57}$ required cigarette packages to adopt the starker warning that smoking is hazardous to health. ${ }^{58}$ But, it also contained a more elaborate preemption clause-Section 5(b).59 That section reads as follows: "No requirement or prohibition based on smoking and health shall be imposed under State law with respect to the advertising or promotion of any cigarettes the packages of which are labeled in conformity with the provisions of this [Act]." 60

In 1983, Rose Cipollone, a smoker who suffered from terminal lung cancer, and her husband Anthony sued three cigarette manufactur-

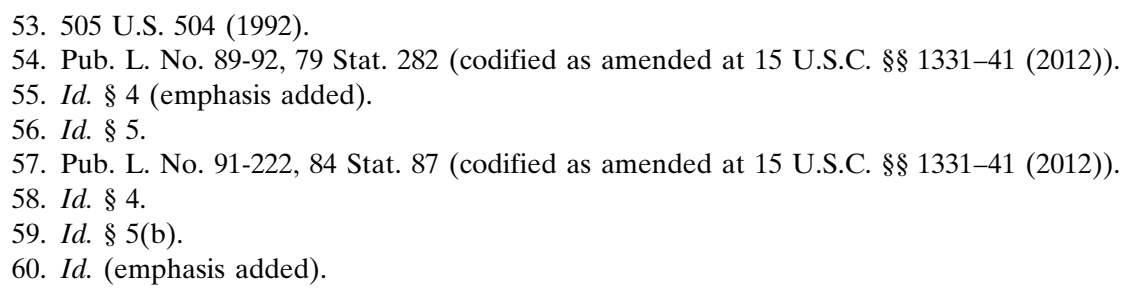


ers. ${ }^{61}$ The suit included claims for design defect, failure to warn, express warranty, fraud, and conspiracy. ${ }^{62}$ After Rose died, Anthony took over her claim as executor of her estate and also asserted a claim on his own behalf for loss of consortium. ${ }^{63}$ Both Rose's and Anthony's claims generated a verdict holding the defendants liable for failure to warn and for breach of express warranty. ${ }^{64}$ However, the jury assigned Rose $80 \%$ comparative fault, which negated any recovery by her or Anthony on the failure-to-warn claim. ${ }^{65}$ Oddly, as to the express warranty claims, the jury awarded Rose no damages but awarded Anthony $\$ 400,000 .{ }^{66}$ Anthony died after the trial, and their son, Thomas, took over both claims. ${ }^{67}$ The defendants appealed, arguing that all claims were preempted by the 1965 and 1969 Acts. ${ }^{68}$

The Court eventually rendered a fractured decision that gave cigarette manufacturers only a modest victory. A plurality-Justice Stevens joined by Chief Justice Rehnquist, Justice White, and Justice O'Connor-concluded that the 1969 Act (but not the 1965 Act) preempted failure-to-warn claims, at least insofar as these claims were premised on the idea that manufacturers could be deemed to have acted tortiously by not providing warnings on packages or in advertisements beyond those mandated by the 1969 Act. The same plurality opinion further concluded that the plaintiffs' remaining claims were not preempted. ${ }^{69}$

Justice Blackmun, joined by Justice Souter and Justice Kennedy, concluded that none of the plaintiffs' claims were preempted by either Act. ${ }^{70}$ This resulted in a seven-Justice majority ruling of no preemption with respect to the plaintiffs' warranty, fraud, and conspiracy

61. Cipollone v. Liggett Grp., Inc., 505 U.S. 504, 509 (1992).

62. Id. at 512.

63. Id. at 509 .

64. Id. at 512. The plaintiffs' design defect claims were dismissed by the trial court and were not addressed in the Supreme Court's preemption analysis.

65. Id.

66. The trial court concluded that the jury's failure to award Rose damages for her warranty claim was clearly erroneous but nonetheless declined to cure the error because plaintiffs' counsel had sought relief by means of a motion for a partial new trial that was limited to damages only. The trial court denied the motion because it concluded that a retrial of the damages issue would require retrial of certain liability issues, hence making a partial retrial impossible. The trial court also ruled that the defendants had failed to properly raise comparative fault as a defense to the plaintiffs' warranty claims. Cipollone v. Liggett Grp., Inc., 693 F. Supp. 208, 216-217 (D.N.J. 1988), aff'd in part, rev'd in part, 893 F.2d 541 (3d Cir. 1990), aff'd in part, rev'd in part, 505 U.S. 504.

67. Id.

68. Cipollone, 505 U.S. at 510.

69. Id. at 517-20 (plurality opinion).

70. Id. at 531 (Blackmun, J., concurring in part, concurring in judgment in part, and dissenting in part). 
claims. Meanwhile, Justice Scalia and Justice Thomas took the view that each of the plaintiffs' claims was preempted under both the 1965 and 1969 Acts. $^{71}$ They thereby provided the votes necessary to garner a six-Justice majority for the proposition that the plaintiffs' failure-towarn claims were preempted by the 1969 Act. The upshot was that litigants suing tobacco companies for tobacco-related illnesses could proceed with express warranty, fraud, and conspiracy claims but not with claims based on inadequate warnings in labeling or advertising.

The subtle split between Justices Stevens and Blackmun turned on their respective views of whether a state court judgment deeming a cigarette manufacturer liable under the common law of tort for failing adequately to warn a smoker of smoking-related dangers amounted to a "requirement or prohibition ... imposed under State law" within the meaning of Section 5(b) of the 1969 Act. ${ }^{72}$ Justice Blackmun argued that common law tort liability is quite different in legal form from state regulations and statutes, and that this difference meant that a tort judgment could not be understood as setting a "requirement or prohibition."73 A holding of preemption was thus unwarranted, especially in light of the presumption against preemption, which Justice Stevens was himself fond of emphasizing.

Facing a creative legal argument by the tobacco companies rooted in the Court's labor preemption cases, Justice Stevens agreed that common law tort claims were not preempted by the 1965 Act. ${ }^{74}$ And, he agreed with Justice Blackmun that it would be insufficiently attentive to federalism concerns if the Court were to read the 1969 Act, which, like its predecessor, was overwhelmingly addressed to state regulation, to preempt all of the Cipollones' claims. But, on the precise issue of the relation between the 1969 Act and the failure-to-warn claim, Justice Stevens was willing to find preemption. ${ }^{75}$ This was, in significant part, because he read Section 5(b)'s emphasis on "advertising and promotion" as indicating a decision by Congress to go beyond the 1965 Act in making sure that manufacturers received the full benefit of the political bargain that resulted in their being mandated to adopt stronger warning language. ${ }^{76}$

71. Id. at 555-56 (Scalia, J., concurring in judgment and dissenting in part).

72. See Public Health Cigarette Smoking Act of 1969, § 5(b), Pub. L. No. 91-222, 84 Stat. 87 (codified as amended at 15 U.S.C. $§ 1334$ (b) (2012)).

73. Cipollone, 505 U.S. at 536 (Blackmun, J., concurring in part, concurring in judgment in part, and dissenting in part).

74. Id. at 535 (Blackmun, J., concurring in part, concurring in judgment in part, and dissenting in part).

75. Id. at 524 (plurality opinion).

76. See id. at 524-25 (plurality opinion). 
Justice Scalia's disagreement with Justice Stevens was similarly rooted in a difference of opinion on how to interpret the express preemption clauses of the two statutes. First, Justice Scalia rejected the assertion that the historical presumption against preemption was applicable when Congress includes an express preemption provision in the relevant statute. ${ }^{77}$ Then, adopting a Holmesian view of law as a threat of official sanction (whether in the form of a regulatory fine or tort liability), Justice Scalia deemed tort liability to be the imposition of a state law requirement on cigarette manufacturers. ${ }^{78}$

As noted, Cipollone and Sullivan differ in many ways. The former was a personal injury claim for compensatory damages while the latter was not. The Court lacked a majority opinion in Cipollone but was unanimous in Sullivan (at least with respect to the proposition that a public official who cannot prove actual malice may not recover). Although both cases challenged state tort law in a manner that ultimately rested on the Constitution, Cipollone involved the powersharing relationship between the federal and state governments while Sullivan involved an enumerated individual right. And, of course, the tobacco company defendants in Cipollone obtained nothing like the complete victory that had been obtained by the New York Times.

Yet these two cases also have important commonalities. In Cipollone, as in Sullivan, the Court felt compelled to modify rules of tort law to prevent tort litigation from undermining or evading a settlement achieved at the level of national politics. In Sullivan, the Court blocked southern political officials' uses of defamation law as a rearguard action against federally mandated desegregation. In Cipollone, a majority thought it was important to block the use of failure-to-warn claims to undermine the resolution of a hard-fought national political battle. The case for intervention in Sullivan was bolstered by broad national support for desegregation as well as a coalescence in midtwentieth century constitutional thought around an understanding of the First Amendment as first and foremost denying governments the power to punish political speech. Obviously, the case for intervention in Cipollone could not purport to tap into fundamental values of this sort. Nonetheless, there was a political background to which the Court could look for support. The settlement brokered in Congress was achieved at a very fine-grained level-it is not often that one finds directives in federal legislation (as opposed to federal regulation) that operate at the level of specificity of the mandated warnings contained

77. Id. at 546 (Scalia, J., concurring in judgment in part and dissenting in part).

78. Id. at 554-55 (Scalia, J., concurring in judgment in part and dissenting in part). 
in the 1965 and 1969 Acts. Moreover, through Section 5(b) of the 1969 Act, Congress incorporated a relatively explicit understanding of how the settlement was to be implemented within the tiers of the U.S. federal system. In short, it was clearly a term of the political bargain: as long as manufacturers complied with federally mandated warnings, they would be protected against state-law pressures to adopt additional warnings.

As in Sullivan, the Cipollone Court did not enter the fray based on any a priori belief of how failure-to-warn tort litigation should work anymore than it exercised and aimed its power in Sullivan to craft libel law. The Court's challenge in Cipollone, as in Sullivan, was extrinsic to tort law. Lawyers for tobacco companies used federal preemption doctrine and extant federal regulatory legislation as a way to limit their exposure to tort liability. But, of course, the defense bar's enchantment with federal preemption did not turn out to be a onenight stand. And, just as Sullivan marked the first step in what would become decades of increasingly intrusive doctrinal development, $\mathrm{Ci}$ pollone marked the first small step in what has since become an elaborate and, indeed, transformative use by the Court of the doctrine of federal preemption.

One need only glance at subsequent preemption decisions, starting with the Court's 2000 decision in Geier v. American Honda Motor Co. ${ }^{79}$ to gauge the distance the Court has travelled from Cipollone and to see why the trajectory of modern preemption jurisprudence raises serious concerns regarding the Court's faithfulness to the spirit of Erie. In Geier, the plaintiff was injured in a car crash and sued Honda, the manufacturer of her 1987 model-year car. Brought under Washington, D.C. law, the suit alleged that the car was negligently and defectively designed because it did not have a driver's side airbag. ${ }^{80}$ Justice Breyer, writing for a bare majority, concluded that the plaintiff's claim was preempted by a regulation-Federal Motor Vehicle Safety Standards and Regulations Standard No. 208 (FMVSS 208) ${ }^{81}$ that had been adopted in 1984 by the U.S. Department of Transportation (DOT). FMVSS 208 allowed car manufacturers to phase in different safety devices into different model-year vehicles between 1984 and 1989.82 According to Geier, a decision to allow the plaintiff to recover would be tantamount to allowing the District of Columbia to require all 1987 model cars sold in D.C. to be equipped with airbags,

79. 529 U.S. 861 (2000).

80. Id. at 865 .

81. 49 C.F.R. § 571.208 (2013).

82. Geier, 529 U.S. at 885-86. 
thereby undermining DOT's decision to grant manufacturers room in the late 1980 s to choose among different safety devices. ${ }^{83}$

The most arresting feature of Geier is the Court's self-aggrandizing reading of the federal statute under which DOT had issued FMVSS 208. Like the federal cigarette labeling laws, the National Traffic and Motor Vehicle Safety Act of 1966 (NTMVSA) ${ }^{84}$ contains a preemption provision. Thus, according to NTMVSA Section 1392(d), once DOT duly establishes a safety standard with respect to a motor vehicle, "no State ... shall have any authority ... to establish, or to continue in effect, . . . any safety standard applicable to the same aspect of performance of such vehicle ... which is not identical to the Federal standard." 85 Taken on its own, this provision might seem to raise the question as to whether the imposition of tort liability on a car manufacturer for an alleged defect would amount to the "establish[ment]" or "continu[ation] in effect" of a state vehicle safety "standard." However, Section 1392(d) cannot be taken on its own. Indeed, Congress seemingly spared courts the need to address this question by answering it. For, alongside its express preemption provision, NTMVSA contains an express savings clause. And that clause, Section 1397(k), quite clearly states that "compliance with" a federal safety standard "does not exempt any person from any liability under common law."86

Section 1397(k)'s unambiguous language quite clearly indicates that Congress did not mean for a manufacturer's compliance with DOT safety regulations to establish a complete defense to tort actions. Instead, evidence of compliance would be admissible on the question of whether a manufacturer exercised due care or adopted an acceptable design. It was hardly surprising that Congress adopted this understanding of the relationship of regulatory law to tort law. The default common law rule has long been that compliance with state safety laws and regulations is relevant to, but not dispositive of, tort liability. By including Section 1397(k), Congress merely affirmed that the traditional approach would continue to apply in this context. By contrast, efforts by states to use their own regulatory agencies to impose conflicting standards on car manufacturers would be preempted.

Undaunted by statutory text, the traditional understanding of regulatory law as a floor not a ceiling, and the historic presumption against

83. See id. at 879.

84. Pub. L. No. 89-563, 80 Stat. 718 (codified as amended in scattered sections of 49 U.S.C.). 85. Geier, 529 U.S. at 867 (emphasis added) (quoting 15 U.S.C. $\$ 1392(d)$ (1988) (repealed 1994)).

86. 15 U.S.C. $§ 1397(k)$ (1976) (repealed 1994) (emphasis added). 
preemption, the Geier majority found a way to deem Geier's common law tort claim preempted. Section 1397(k)'s savings clause, the Court reasoned, meant that plaintiff's claims were not preempted simply by operation of Section 1392(d)'s express preemption clause. ${ }^{87}$ The entire effect of Section $1397(\mathrm{k})$, in other words, was to cancel out Section 1392(d) as it might otherwise have applied to tort claims. This left the Court with the task of determining for itself whether tort liability would so significantly interfere with the operation of federal regulations as to frustrate the purpose of Congress, thereby giving rise to "implied" preemption even in the face of the statute's savings clause. ${ }^{88}$

Whatever might be said about the validity of implied preemption analysis when a federal statute is silent as to its preemptive effect, Geier's assertion of the authority to find implied preemption in the face of an express savings clause is extremely aggressive. If Erie was remarkable for its abandonment of lawmaking power, Geier is no less remarkable for its assertion of this power. Indeed, Geier's particular application of implied preemption doctrine is barely distinguishable from a claim to have authority to fashion general law. The powerful Geier dissent, penned by Justice Stevens on behalf of himself and three colleagues, is no less striking. For, notwithstanding its emphasis on the presumption against preemption, it did not directly challenge the majority's questionable resort to implied preemption analysis. ${ }^{89}$ Instead, it argued, more weakly, that NTMVSA's savings clause should be understood to put a thumb on the scale against a finding of implied preemption. ${ }^{90}$

From Geier we turn briefly to Riegel v. Medtronic, Inc. ${ }^{91}$ In Riegel, the Court deemed that negligence and products liability claims against the manufacturer of a medical device (a balloon catheter) were preempted on the ground that the device had been reviewed and approved by the federal Food and Drug Administration (FDA) according to protocols set out in a federal statute known as the Medical Devices Amendments of 1976 (MDA). ${ }^{92}$ The MDA contains a preemption provision that largely tracks the preemption provision of the NTMVSA. The clause bars states from establishing any requirements pertaining to the safety or effectiveness of a particular medical device that differ from applicable federal requirements for that de-

87. Geier, 529 U.S. at $869-74$.

88. See id. at 869 .

89. See id. at 886-913 (Stevens, J., dissenting).

90. See id. at 895-98 (Stevens, J., dissenting).

91. 552 U.S. 312 (2008).

92. Id. at 327-30. See generally Medical Devices Amendments of 1976, Pub. L. No. 94-295, 90 Stat. 539 (codified as amended in scattered sections of 21 U.S.C.). 
vice. ${ }^{93}$ Because the device in question had been approved for sale only after a safety review by the FDA, the Riegel Court-in an opinion written by Justice Scalia-concluded that a finding of negligence or design defect would amount to the establishment of state law "requirements" pertaining to the safety of the device that were different from the requirements set by the FDA as a condition for approval. ${ }^{94}$ Accordingly, it deemed the plaintiff's tort claims preempted. ${ }^{95}$

In some respects, the Court was less aggressive in finding preemption in Riegel than it was in Geier. For one thing, there was no savings clause in the MDA and, for another, Riegel depended on express rather than implied preemption. But Riegel was aggressive in other ways. Its sweep is enormous: it cuts off all design defect claims by an injured plaintiff against the manufacturer of a medical device that has cleared the FDA's full approval process. And, its justification depends on an interpretation of the MDA's preemption clause that, while colorable, is quite artificial. As Justice Ginsburg's dissent demonstrated, the FDA, under the authority of the Food, Drug, and Cosmetic Act (FDCA), ${ }^{96}$ had, for decades, operated a pre-approval program for drugs that involved review comparable to full review of medical devices under the MDA. ${ }^{97}$ Yet, there had never been any suggestion that the FDA's preapproval process for drugs immunized drug manufacturers from tort liability. Quite the opposite; a drug manufacturer's compliance with FDA requirements was understood on the traditional floor-not-ceiling terms-as relevant to, but not dispositive of, issues such as negligence and design defect. To be sure, the FDCA, unlike the MDA, contained no express preemption provision. But, it is fairly clear that Congress added that provision to the MDA not to cut off state tort law claims but, rather, to fend off the emergence of state regulatory regimes for medical devices. ${ }^{98}$

Thus, in Riegel, too, one sees that the Court now understands itself as commissioned by the Supremacy Clause to search out and eliminate tort liability that it regards as too greatly interfering with the operation of federal regulations. This might be a defensible assignment for the Court to give itself with respect to tort doctrines that actually inhibit or prevent agencies, such as the DOT and the FDA, from performing their statutory duties. But, there is little, if any, evidence of

93. Medical Devices Amendments $§ 521$.

94. Riegel, 552 U.S. at 321-23.

95. Id. at 330.

96. Ch. 649, 52 Stat. 1040 (1938) (codified as amended in scattered sections of 21 U.S.C.).

97. Riegel, 552 U.S. at 339 (Ginsburg, J., dissenting).

98. Id. at 341 (Ginsburg, J., dissenting). 
interference of this sort in Geier or Riegel. Rather, the interference is described abstractly as a frustration of Congress's broader regulatory purposes. In any event, the majorities in these decisions seemed less concerned for the plight of federal regulators and more concerned with the plight of regulated entities who have supposedly been placed in a difficult or unfair position by having to comply with both federal regulatory law and state tort law. Yet, as noted above, actors subject to overlapping regulatory and tort law have always faced this situation. It is only quite recently that anyone has thought it to be untenable. ${ }^{99}$

If Riegel's recognition of de facto immunity for medical device manufacturers was close to a fabrication, why was it a nearly unanimous decision and why has it received so little scholarly criticism? Part of the answer, we believe, takes us back to an issue that was central to Cipollone. Recall that Justices Stevens, Blackmun, and Scalia battled over whether the existence of state common law products liability doctrines amount to a "requirement" set by state law. 100 Justice Blackmun had reasoned that state tort law does not set requirements and, thus, could not be preempted by either the 1965 or 1969 Acts. Justice Stevens had concluded that some tort rules set requirements (and hence were preempted) whereas others did not. Justice Scalia, meanwhile, had asserted that all forms of tort liability at issue in $\mathrm{Ci}$ pollone constitute requirements and hence all should have been deemed preempted.

Just four years after Cipollone, Justice Scalia's position had gone from attracting only one colleague (Justice Thomas) to being the majority view. In a precursor to Riegel-the Court's 1996 decision in Medtronic, Inc. v. Lohr ${ }^{101}$ - a divided Court concluded that the MDA did not preempt liability for injuries caused by medical devices that receive only cursory FDA review prior to being approved for sale to the public. ${ }^{102}$ Justice O'Connor, writing a dissenting opinion for herself and Justices Rehnquist, Scalia, and Thomas, asserted: "Whether relating to the labeling of cigarettes or the manufacture of medical devices, state common-law damages actions operate to require manufacturers to comply with common-law duties."103 Given that, on this view, "state common-law damages actions do impose 'requirements[,]" it followed that any tort liability imposed for injuries

99. See supra note 8 and accompanying text. 
caused by FDA-approved devices, no matter how cursory the FDA's review, must be preempted. ${ }^{104}$ Meanwhile, although he joined the majority in rejecting the defendant's preemption argument, Justice Breyer, in his concurring opinion, accepted this aspect of Justice O'Connor's analysis. ${ }^{105}$ In short, by 1996-with Chief Justice Rehnquist and Justice O'Connor having moved from the qualified position expressed in Justice Stevens' Cipollone plurality opinion to the absolutist position staked out by Justice Scalia's Cipollone dissent (joined by Justice Thomas) and with Justice Breyer having replaced Justice Blackmun - a majority had accepted the absolutist approach. Indeed, Justice Stevens would later virtually concede this point in his ambivalent concurring opinion in Riegel. ${ }^{106}$

As scholars who have argued against the view that tort law is merely a collection of liability rules and who have instead insisted that tort law-including many versions of the law of "strict" products liability-sets genuine duties of conduct, we might seem ill-suited to reject the view that tort law can set "requirements." Yet, we do reject that view, and for good reason. The question at hand in tort preemption cases is how one should understand Congress's declaration that inconsistent state requirements are preempted. On that issue, we think it overwhelmingly clear that even though tort liability does hold defendants accountable for breaches of genuine obligations, Congress, in statutes such as the NTMVSA and the MDA, did not contemplate that tort liability would count as a requirement or prohibition. To say the same thing: tort duties are requirements, but they are not the requirements to which these statutes referred. It is also more than a bit ironic that Justice Scalia had no qualms anachronistically reading a very modern, regulatory view of tort law into the language of statutes adopted in an earlier time. Finally, the broad Lohr-Riegel conception of what counts as a requirement is especially inapt to a part of tort law (products liability) that is notable for its embrace of strict liability.

The larger picture, however, is that even as to common law negligence claims, the depiction of state tort law as containing requirements of a sort generating preemption is indefensible. This depiction relies on an equivocation between two different layers of duty within the common law of torts. When a jury reaches a plaintiff's verdict in a

104. Id. at 509 .

105. Id. at 503 (Breyer, J., concurring in part and concurring in judgment).

106. Riegel v. Medtronic, Inc., 552 U.S. 312, 332-33 (2008) (Stevens, J., concurring in part and concurring in judgment) (footnote omitted) ("And although not all common-law rules qualify as 'requirements,' the Court correctly points out that five Justices in Lohr concluded that the common-law causes of action for negligence and strict liability at issue in that case imposed 'requirements' that were pre-empted by federal requirements specific to a medical device.”). 
negligence case and a court enters judgment on the verdict, the defendant faces liability. And, it is true that the state's legal system has seen fit to impose liability on the ground that-according to the jurythe defendant breached a duty not to injure the plaintiff through a certain kind of conduct. However, the duty to refrain from negligently injuring and the duty to take care exist at a level of generality in state tort law that is entirely different from the obligation of the defendant to pay the plaintiff once a judgment is entered. For preemption purposes, the question is whether the duty of conduct-the duty to be careful as to the physical well-being of foreseeable victims - is preempted by federal law. The fact that a judge or jury in a particular tort case has found that the defendant breached a duty of care by injuring the plaintiff is quite distinct from a state legislature or regulatory body declaring that certain conduct is prohibited or required. Likewise, a state's maintenance of laws, through which an actor can be held liable to provide redress to an injury-victim on the basis of certain findings, is a far cry from state regulation.

The Court has come a long way since Cipollone. By recognizing various different forms of preemption-express preemption, frustration-of-purpose preemption, impossibility preemption, and occupation-of-the-field preemption-it has given repeat-player products liability defendants vast protections from state law tort liability. In 2016, a plaintiff's rights to recover damages in a products liability action under common law are greatly diminished from what they were in the early 1990s. Through the doctrine of preemption, the Supreme Court has now effectively immunized the manufacturers of generic drugs-over $75 \%$ of the market for drugs in 2009-from products liability claims. ${ }^{107}$ The same is true with respect to manufacturers of medical devices that go through the FDA's full preclearance procedures. Promising preemption arguments are open to manufacturers in a wide variety of areas in which Congress has never passed any sort of regulatory statute, let alone one with a preemption clause. And, we are not even mentioning the additional limitations that the Court's Daubert and punitive damages decisions have imposed on state products liability law.

Preemption is now front and center in modern tort law because the Court did not let Cipollone stand as a one-off reading of a particular statute. Instead, the Court has granted certiorari in dozens of cases since, and it is has gradually moved, albeit inconstantly, in a direction that is as hostile to negligence and products liability plaintiffs as it is to

107. Pliva v. Mensing, 131 S. Ct. 2567, 2584 (2011) (Sotomayor, J., dissenting). 
libel plaintiffs. In these areas of tort law, as in libel law, Erie now tends to be honored in the breach.

\section{CONClusion}

Notwithstanding their many differences, the Supreme Court's defamation and preemption decisions have traveled down a similar path. Called on to intervene on behalf of defendants with a compelling claim to protection from a certain kind of liability, the Court granted relief on terms that inevitably invited further petitions, which, in turn, gave rise to a body of federal law that has largely displaced applicable tort law.

Sullivan offered a particular and readily justified holding: officials may not use civil defamation law to bring seditious libel prosecutions. However, because that decision was framed by the Court as raising a deep conflict between the right of free speech and defamation law, it quickly gave rise to a general law of defamation. The supposed vulnerability of speech to the "chilling effect" of tort liability would become an argument that few Justices have been able to resist.

Cipollone was a cautious decision. Given two federal statutes that not only contained preemption clauses (and no savings clauses), but also mandated a highly specific warning about the dangers of smoking, the Court concluded that tort plaintiffs suing tobacco companies, although free to pursue various theories of wrongful injury, were barred from pursuing the particular theory that cigarette advertisements and packages had inadequately warned them of smoking's dangers. Again, however, lurking in a narrow decision was the basis for a much broader assault on tort law. For once tort law was understood as, at least on some occasions, setting "requirements," it only took a short step to conclude that state tort law, in general, makes demands on regulated entities incompatible with those of the federal regulatory state.

Because in each case there was a constitutional basis for the Court's intervention, the Justices can, with a straight face, claim not to have abandoned Erie. But, by framing the constitutional concerns raised by these cases at a high level of generality and by assigning themselves the task of addressing these concerns wherever they arise, the Court went a long way toward fashioning its own federal tort law of libel and products liability. As briefly suggested above, we believe that parallel stories can be told about the emergence of a federal tort law of privacy, punitive damages, causation in toxic tort cases, and elsewhere. ${ }^{108}$ 
It has long been the job of state courts to establish common law rules that govern interactions between and among private parties and to define our rights and duties in relation to one another. In some cases, the application of these rules raises pressing issues pertaining to the relationship between states and citizens, such that it would blinker reality to treat those cases as merely raising matters of private law. This was true in Sullivan and Cipollone. It hardly follows that private law always, or even usually, runs afoul of public law or that the Court should be looking for excuses to revise extant state private law with new rules that it believes are more consonant with public law frameworks and values. The line between public law that regulates and private law that redresses wrongs is not always sharp. Still, the two are by no means one and the same thing. Whenever it finds itself making doctrine in the heartland of torts, the Court should recognize that it is likely homogenizing, distorting, and federalizing a body of state law to which individuals are entitled as a matter of common law and as a matter of right. 